Article

\title{
Heroes and Social Criticism in the Works of Valeria Anderson
}

DE DE GRUYTER

OPEN

RIHO VÄSTRIK, Tallinn University, Estonia; email: vastrik@tlu.ee 


\section{ABSTRACT}

This article investigates how director Valeria Anderson constructed heroes in the documentaries she directed between 1960 and 1985. It also asks how far one could go with social criticism in the post-Stalinist/pre-Perestroika era, how pointed the revelations of economic disorder could be, and what rank of leadership could be blamed for the occurrences of these problems. The article concentrates on the documentaries made by Valeria Anderson that depict positive heroes sacrificing their personal interests for the good of the homeland. The narratives are examined by using discourse analysis.

Having graduated from the All-Union State Institute of Cinematography (Всесоюзный государственный институт кинематографии, VGIK), Valeria Anderson (Figure 1) joined the Tallinn Film Studio as a documentary film director in 1959. At the time, the Tallinn Film Studio was focussed mainly on producing films that conformed to the canons of socialist realism. Anderson worked at the same studio until her retirement in 1989, directing a total of 29 documentaries. She is considered to be a pioneer of the critical approach in Estonian documentary film.

It is commonly accepted that the administration of the Soviet Union relied on the heroism of its citizens to compensate for the shortcomings in the economy, social sphere and security. Heroes and heroic acts were everyday occurrences in the Soviet Union. The ruling ideology fostered the notion that the people themselves wanted to be heroes and were willing to sacrifice their personal interests, and if necessary, their very lives, for the collective good.

According to Anton Makarenko (1888-1939), the new Soviet Man was someone for whom the collective perspective took precedence over the personal (Власов 1974: 6). Makarenko was one of the most influential educational theorists and practitioners in the Soviet Union, who simultaneously promoted democratic ideas and a strict military discipline.
Constructing these kinds of heroes in film was very much encouraged. Their struggle with 'problems' was glorified, while the existence of shortcomings was also recognised.

This article sets out to explore the process of constructing the mainstream discourse in Soviet Union during and after the Khrushchev Thaw, and more specifically, the process of constructing social meaning, primarily heroism and culprits of social problems, in Soviet Estonian documentary film from 1960 to 1985. The main focus is on the social background of the constructed heroes, the environment they operate in, what they do, to whom they are subordinated and with whom they are contrasted.

\section{HISTORIOGRAPHY}

After Joseph Stalin died and Nikita Khrushchev condemned his cult of personality, art in the Soviet Union liberalised at whirlwind speed. The creative intelligentsia (including filmmakers) was at the forefront of uprooting Stalinist dogmas (Dumanĉić 2010: 9). In just a few years, socialist realism was relegated to the status of a pariah, and there was a longing for art that depicted real life and daring experiments, instead of ideal humans in sanitary conditions. These 
trends were also reflected in film scholarship and criticism. In order to map the background system, I have researched the articles by Soviet film scholars and critics published in the Искусство кино journal. This provides a good basis for understanding both the official ideology and the discussion that emerged in the art community regarding the trends that deviated from the more conservative approach of the Communist Party of the Soviet Union (CPSU), primarily in regard to the mutual impact of ideology and art. For the same reason, I have also studied the periodicals of the Estonian SSR, especially the cultural weekly Sirp ja Vasar.

In 'The Hero of Our Day' ('Герой наших дней'), Alexander Karaganov asks whether a positive hero must be ideal to the core or whether flaws and imperfections are needed to bring the character alive. He asks what proportion of positivity and negativity should be present for the hero to 'reflect the revolutionary developments of reality, a part of which is the character's development' (Караганов 1959: 39). According to Karaganov, the artist's position should always remain active; art should embody 'the dialectics of poetic justice' and not portray stupidity as good, or the small as large (Караганов 1959: 40).

These are bold statements from the perspective of creators, but further along, Karaganov follows with the official party line:

The Communist Party is consistent in encouraging Soviet artists to create works with vibrant positive heroes who would be inspiring role models for their fellow citizens. The Party supports the artists who view creating the image of positive heroes as paramount in their creative work. (Караганов 1959: 40)

In 'A New Individual on the Screen' ('Новый человек на экране'), Boris Agapov emphasises the importance of image in documentary film: 'If the aim is to create a human image on the screen instead of an informative image of a human, the human must be felt and then appropriately expressed' (Агапов 1959: 24). Agapov discusses the role of the director and camera under the new circumstances and concludes that "the documentary filmmakers of our time do not stand apart from the objects of their study. Rather, they are social actors with film shots as their weapon' (Агапов 1959: 24).

In 'Heroism in Film' ('Героическое в кино'), Vladimir Baskakov offers a criticism of the pre-Thaw tenure of Stalin, who prompted artists to tamper with and misrepresent the events of World War II (the Great Patriotic War in the USSR). Instead of films depicting the heroic deeds of Soviet soldiers, Stalin favoured films about ancient warlords, all of whom were intended to channel Stalin himself (Баскаков 1964: 36). The 20th Congress of the CPSU liberated cinematography from this burden.

A decade later during the tenure of Leonid Brezhnev, Marat Vlasov, in his article 'The Hero the Time Needs' ('Герой, которого требует время'), discusses the modernisation of the cinematic process from a political, aesthetic and organisational perspective. In his musings, the author highlights a person who has helped the Bolsheviks create and protect the country and who is making a self-effacing contribution to the blossoming of material welfare. His language reflects the pathos of the time: the birth of a new individual; the dynamics of the inner transformation of the hero; the formation of the socialist personality type; the dominance of pioneering elements over backward remnants; moral issues of concern for the contemporaries, etc. (Власов 1974). However, at the same time, Andrey Shcherbenok claims that the cinema of the Era of Stagnation can be called a cinema of exhaustion, because the social reality reflected on the screen looked untidy and ferial, as well as unconvincing regarding the idea that the Soviet state is everlasting (Shcherbenok 2016: 77-78).

Russian authors have published various studies of film covering the entire Soviet period, of which Documentary Illusion. Domestic Documentary Film: Experiences in Social Creation (Документальный иллюзион. 


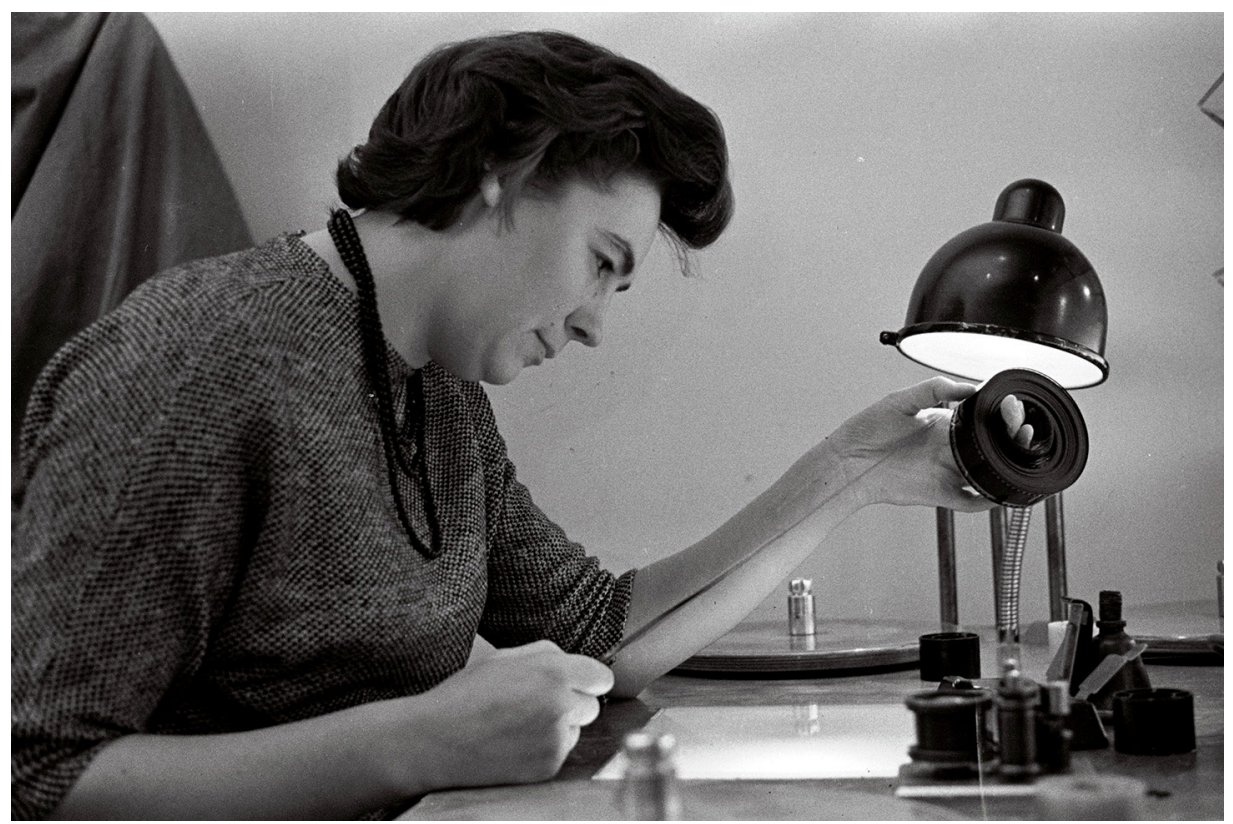

FIGURE 1. Valeria Anderson. Photo by Armin Alla, 1963

(Film Archives of the National Archives of Estonia, EFA.331.0-83120). 
Отечественный кинодокументализм - опыты сочиального творчества) by Lyudmila Dzhulai (Джулай 2005) and the comprehensive anthology by Valeri Fomin, A History of Russian Cinema: Management, Production, Distribution (История киноотрасли в России: управление, кинопроизводство, прокат; Фомин 2012) have had the greatest impact on the discussion below.

Reviews of contemporary documentaries were also published in the periodicals of the Estonian SSR. However, this occurred sporadically and usually before one of the larger cinematographers' meetings. In 1962, Semjon Školnikov, Chairman of the Organising Bureau of the Union of Cinematographers of the Estonian SSR, said that Ivar Kosenkranius is the only film critic in the republic with the appropriate educational background, and that film critics have completely forgotten documentaries (Anonymous 1962). Fifteen years later, the situation had not significantly improved: 'Two or three significant articles about film are published by a few authors' (Elme 1977). Later, in 1983, a jury appointed by the board of the Union of Cinematographers to evaluate film reviews had to admit that 'only a few film reviews were published last year, all of them substandard' (Anonymous 1983b). One of the most frequent writers in the 1970s was Tatjana Elmanovitš, who was also the only film scholar in the ESSR with a postgraduate degree in film studies. In addition to Elmanovitš, Ivar Kosenkranius, Valdeko Tobro, Jaan Ruus, Heli Speek and others also wrote articles analysing the current situation. A decade later, Sulev Teinemaa wrote a descriptive overview of Valeria Anderson's oeuvre, focusing on the so-called problem film (Teinemaa 1983). Film criticism by Ivar Kosenkranius was published as an anthology called Film and Time: Essays, Etudes, Portrait Outlines (Film ja aeg. Esseid, etüüde, portreevisandeid; Kosenkranius 1974). Tatjana Elmanovitš analysed Estonian television documentary in The Figure of the Fact: From Journalism to Filmmaking in Estonian Television (Образ факта. От публицистики к фильму на эстонском телевидении; Эльманович 1975).
The trends in documentary development are in many ways comparable to the developments in narrative cinema, journalism, literature, theatre and the visual arts. The specifics are different, but the political environment is the same. Tiiu Kreegipuu has studied the print media in Soviet Estonia, and shown that journalists worked in a context ideologically similar to that of documentary filmmakers - they were looking for heroes, 'real people' and achievements to be presented as victories (Kreegipuu 2015). Examining the shifting values of Soviet media during the transition from the Khrushchev Thaw to Brezhnev's Era of Stagnation, Simon Huxtable believes that 1964-1968 constitutes a crucial moment. Between 1964 and 1968 the regime's tolerance of 'permitted dissent' began to diminish and a shift from discourse to dogma became ever more apparent as the media turned into a repository of the 'authoritative discourse' of late socialism (Huxtable 2016: 23).

The common periodisation of the Soviet period in Estonia also applies to documentary cinema: the Stalinist 1940s and 1950 s were followed by the so-called Thaw, which in the early 1970s was replaced first by the Era of Stagnation, and then the Perestroika of the 1980s. The greatest advantage that the visual artists had over the documentary filmmakers was that the former could produce works based on their own convictions and hide them 'behind the cabinet', and only share them privately with trusted contemporaries. The documentary cinema, by contrast, was a state-funded and controlled field where the author created, figuratively speaking, 'in the full view of everyone'. Searches for the hero and the 'real person' were also very topical in the theatre. Symptomatic were the constant declarations that there are too few works portraying modern and contemporary people (Vellerand 1983), while at the same time, praising the fact that the Soviet authors in other republics are dealing specifically with these issues. Existing research does not provide a detailed analysis of the context in which the documentary filmmakers of 
the Soviet-occupied Estonian SSR worked. However, Estonian documentary film also reflected the Soviet reality and heroes.

\section{AN AUTHOR ALWAYS CREATES WITHIN A CONTEXT}

An audiovisual work is a complex text consisting of a verbal text and other audiovisual elements. Visual images also become a language when they are used for expressing meaning: 'Any sound, word, image or object which functions as a sign, and is organised with other signs into a system which is capable of carrying and expressing meaning is, from this point of view, "a language"" (Hall 2013: 5). As texts are born in specific political contexts, it is possible to explore how the context is reflected in these texts. A text creates meaning through the author's choices and thus shapes reality (Kasik 2008: 10-12).

Analysing the interaction of power and knowledge, Michel Foucault has suggested that the mechanisms of power function like a capillary, 'reach[ing] into the very grain of individuals, touch[ing] their bodies and insert[ing] itself into their actions and attitudes, their discourses, learning processes and everyday lives' (Foucault 1980: 39). As Stuart Hall summarises, Foucault was looking for the rules and practices that shape and regulate what can be said and known at any given moment in history (Hall 2015: 29). Foucault found that things mean something and are 'true' only in a particular historical context (Hall 2015:31).

Film is the art of combining and organising, where meaning, emotions, etc. are created by editing (Aumont et al. 2012: 57, 71). Moreover, the associations of ideas induced by editing may produce definite thoughts, logical deductions and conclusions in us (Balázs 1952: 128). In 1962, the Soviet film scholar Sergei Drobashenko lauded the modern editing techniques of documentary film, which made it possible to

set complicated artistic tasks, to raise the great questions of life and depict them by mobilising the richest expressive tools of figurative film journalism. The dynamics of changing frames, the rhythmic repetitions of images create a certain atmosphere, a poetic mood in a film - similarly to the way the alternation of stanzas functions in poetry. (Дробашенко 1962: 147)

A filmmaker uses editing to elevate mundane facts and documents 'to a higher form of art created by a passionate emotional and political content' (Дробашенко 1962: 147; see also Эйзенштейн 1964, Вертов 1966). In other words, editing allowed the author to say things not uttered verbally, i.e. 'to write between the lines'. Therefore, more than any other element of film 'grammar', my analysis will focus on editing.

Peter L. Berger and Thomas Luckmann regard society as an existing subjective and objective reality. Subjective reality originates from the interaction between people and the social realm, whereas the social realm also affects people, resulting in the emergence of routines and conventions (Berger, Luckmann 1991: 69). Therefore, each oft-repeated action becomes a part of a pattern, which can be reproduced without much effort (Andrews 2012). The theory whereby the knowledge of the world is socially conditioned is called social constructionism.

It was widely acknowledged that critical situations were resolved in the Soviet Union by heroic deeds; this was considered 'normal' by both the citizens and the party system. Based on social constructionism, I will set out to examine how Soviet society constructed heroes and how documentary films depicted heroic deeds. I will also explore who were assigned the roles of being the culprits responsible for the problems and dissonances.

According to Hall, Foucault had the concept that 'any topic is constructed by discourse that defines and produces the objects of our knowledge, governs the way in which the topic can be meaningfully talked about and reasoned about.' The discourse also affects how ideas are implemented in practice and used to 
regulate human behaviour (Hall 2015: 29). In Foucault's words:

in a society such as ours, but basically in any society, there are manifold relations of power which permeate, characterise and constitute the social body, and these relations of power cannot themselves be established, consolidated nor implemented without the production, accumulation, circulation and functioning of a discourse. There can be no possible exercise of power without a certain economy of discourses of truth which operates through and on the basis of this association. We are subjected to the production of truth through power and we cannot exercise power except through the production of truth. (Foucault 1980: 93)

I consider it important to map how the Soviet mainstream discourse was constructed in order to proceed to a comparison between it and the discourse of specific documentary films. To that end, I will describe the film criticism of the time and the principles that prevailed in journalism. These will help to delineate the trends that framed artistic production.

For my analysis, I chose three socalled 'critical' documentaries that were filmed in different decades, and each of which resulted in different historical contexts. Historically, the films correspond to the Khrushchev Thaw, Brezhnev's Era of Stagnation and the pre-Perestroika era. All three films are similar in that they are directed by women and have women as their heroines. This was rather unusual for the post-Stalinist era, not to mention the preceding period of socialist realism, which focussed on supermen toeing the party line. However, this article does not aim to explore gender roles, and the sample is based not on the gender of the heroes, but the sociocritical nature of the films. Valeria Anderson was considered to be an author with a keen eye who saw the bitter problems of life (Teinemaa 1983).

\section{SOVIET DOCUMENTARY FILM BEFORE THE KHRUSHCHEV THAW}

Before turning to the analysis of the period I have focussed on, it is necessary to sketch out the key developments that characterised Soviet non-fiction cinema during Stalin's era and right after it. The main historical factors that have influenced the nature of documentary film are the development of art, particularly film, the socio-political and technological processes in society, the expectations and needs of the audience (or requirements of the state) as well as the talent and original ideas of the filmmakers. In a little more than the century that film has existed in the world, a documentary film discourse has emerged and is constantly keeping up with the changes in political, aesthetic and humanistic concepts.

Art (including film) developed in the Soviet Union somewhat differently than in the Western world, mainly because the country was a socio-political experiment that opposed the pre-existing social order and in doing so, was based on a publicly declared dictatorship (of the proletariat). The country was governed by the Communist Party, whose congresses ${ }^{2}$ established goals for the upcoming years in all walks of life $^{3}$ (including the arts). These goals were abided by without contestation, at least at the rhetorical level. Soviet film established a conscious contrast with Western cinema, declaring that it intended to create a new Soviet Man, whereas in the West film had resigned itself to merely documenting processes as an observer (Агапов 1959: 26). Cinema turned to emphatically rhetorical means of expression, giving dominance to affecting styles and forms (Nichols 2001: 142).

As of 1961, every five years; prior to that, irregularly.

3 In terms of cinema, the 20th (1956) and the 24th (1972) CPSU Congresses were most significant. 
Soviet Russia used film for explicitly propagandist purposes ${ }^{4}$ before the other great powers followed suit. ${ }^{5}$ The Cinema Department (Киноотдел, Госкино) was added to the People's Commissariat for Education (Народный комиссариат просвещения РСФСР) in 1919, after the nationalisation of the film industry. The VGIK film school, which still exists, was founded in the same year (Ellis, McLane 2008: 27). Anti-Bolshevik works were banned after the coup. ${ }^{6}$ Justifying and promoting Bolshevism became the norm, while eternal values and idealistic dreams characteristic of Romanticism were rejected. The need to communicate Bolshevik values to the masses was urgent and immense. Jumping ahead, that need had not yet subsided by the time the Soviet Union was dissolved in 1991.

Initially, in the 1920s, the Bolsheviks' 'experiment' allowed the artists to come up with bold experiments and declarations. In the same decade, Europe experienced an era of aesthetic and political modernism, where filmmakers tried to create new forms by mixing documentary reality with narrative fiction and avant-garde experiments (Ellis, McLane 2008: x). In Soviet Russia, there was a need/commission to create new art that would contrast with the rest of the world. That period yielded the experiments of Dziga Vertov and Sergei Eisenstein's innovations in montage theory. However, the free spirit of modern art does not suit totalitarianism ${ }^{8}$, which is why Stalin started restricting creative expression. In 1925, the

The Bolshevik leader Vladimir Lenin declared: 'Of all the arts, for us the cinema is the most important' (Ellis, McLane 2008: 27).

$5 \quad$ The US in the 1920s, Great Britain in the 1930s, Nazi Germany in the 1930s. During World War II, documentary film was part of state propaganda everywhere.

$6 \quad$ On 23 April 1919 the Council of People's Commissars issued a regulation that required, inter alia, that all books that did not cater to the needs and duties of contemporary socialist proletariat culture should be removed from sale (Veskimägi 1996: 20).

$7 \quad$ The discussion posited that film should not be merely a copy of the real world, but a new vision of the world envisioned by the artist. Soviet film theory celebrated the montage theory, which transcended the reproduction of mechanical reality and instead constructed something new in a manner that only cinema was able to (Nichols 2001: 89).

8 For example, the Nazis banned Expressionism soon after they gained power.
Central Committee of the C(b)P passed a famous resolution on literature; in 1928 all art forms were taken under the strengthened control of the party (Taylor 1979: 102). In 1934 the Soviet Writers' Congress established socialist realism as the official artistic canon (Dumancić 2010: 46), other artistic styles were banned, and artistic groups dissolved.

Art rallied around a hyper-masculine protagonist, thus emphasising the patriarchal social structure. Female heroines were given secondary roles that supported the men. Gender became an imposed social category. Referring to Joan W. Scott, Marko Dumanĉić writes that gender is the primary method for emphasising power relations, as it is a foundational element in social relations, being based on socially constructed differences between the genders (Dumanciić 2010: 19). Russia had been a patriarchy before the Bolshevik coup and remained one during the dictatorship of the proletariat.

Socialist realism was interpreted according to the decisions of the Communist Party; there were no definite or unequivocal rules. During the period of Stalin's cult of personality, from the 1930 s to his death in 1953, cinematographers also had to adjust their focus to suit the tastes of the maniac. More dramatic shifts began during World War II, with the massive staging of battle scenes to make them look more impressive. The aim was to please the master of the Kremlin, who largely based his worldview on the movies he watched in his private cinema. Staging spread like wildfire in documentary film (Фомин 2012: 718). Admittedly, the staged or semi-documentary style was also widespread in the West during and after World War $11 .{ }^{9}$

During the post-war period, staging became an all-important principle in Soviet documentary cinema. The filmmakers had little choice when it came to subject matter; even newsreels had to feature ceremonial

For example, the Oscar-awarded Target for Tonight by Harry Watt (UK, 1941) and On the Bowery by Lionel Rogosin (USA, 1957) that won the Best Documentary award at the Venice Film Festival. 
sequences (Фомин 2012: 718, 876). Under these circumstances, a 'powerful' documentary series on the Union Republics and friendly socialist countries was produced. These films completely glossed over the grim realities of the difficult post-war years. A common formula applied: industrialisation followed by agriculture, then culture and finally the arts - song and dance, festivities with jubilant crowds and towering portraits of the 'leader' against the backdrop of the sky (Фомин 2012: 879).

The Estonian SSR was depicted in a similar 'feature-length artistic documentary' called Soviet Estonia (Nõukogude Eesti, Estonia, 1946). The appointed director was Lydia Stepanova from the Moscow Central Studios for Documentary Film, who had already garnered acclaim in the genre; her film crew of 13 people was dispatched to the Tallinn Film Studio. They were provided ample resources, unheard of at the time, and all the county and city executive committees were ordered to assist in the shooting (Kanter 2014: 71-72). The result was a sugar-coated ode, with perfectly positioned milkmaids in gleaming white coats toiling in the field and 'a random citizen' stopping in the shot with a fresh newspaper in hand which happened to include a photo of comrade Stalin displayed under a hollow slogan in block letters. The state, i.e. the Communist Party, had the greatest possible admiration for the end result: the creative team of Soviet Estonia (Lydia Stepanova, Vladimir Tomberg and Semjon Školnikov) was awarded the Stalin Prize, First Class in June 1947 (Летопись 2010: 57).

While the artistic documentary genre was officially declared inappropriate in 1950, the penchant for staging and false ceremonialism took a long time to fade from Soviet documentary film. All these tendencies still existed at the Tallinn Film Studio in the late 1950s and early 1960s, when a generation of young Estonians joined the studio. ${ }^{10}$

\section{THE THAW BRINGS NEW OPPORTUNITIES}

After Stalin's death in 1953 and Khrushchev's speech at the 20th Congress of the CPSU in 1956, where he criticised Stalin, the quest for self-expression exploded among Soviet artists. Passionate discussions on the creation of the Soviet personality type and the role of film in it re-emerged. Socialist realism fell under scrutiny; artists began experimenting with Western modes of expression. Humanism was redeemed. The film historian Vladimir Baskakov found a major humanistic aspect in the content of Soviet art, "which is humane in the true meaning of the word' (Баскаков 1964:36). It was also acceptable for art to again address the meaning of life and eternal existential questions. The poetic mode began gaining popularity, allowing the artists to communicate messages to the audiences that even celebrated national identity (Västrik 2015, Ansip 2006 and 2013).

Discussions revolved around the art of tomorrow and innovation in art. Some associated innovation with the aesthetic leftism of the 1920s, while others were of the opinion that

the road to tomorrow is paved not by epigonic repetitions of the past, but by bold creative quests - including the quest for a new truth, a quest for the mundane, the psychological and the new relative, which resonate with the mental and emotional constitution of the contemporary person. (Караганов 1959: 44)

Post-Stalinist film scholars agreed that the protagonist of Soviet film is the hero, a new personality type: the new Soviet Man,

the builder and protector of a new society; a society that was born of the October fires, grew up and toughened during the formative years of socialism and had its resolve and strength tested in the cauldron of the Great Patriotic War. (Баскаков 1964: 34) 
The most difficult and important task of documentary filmmakers was showing contemporary people, focusing on people who carried out heroic acts 'without loud words, not for the accolades' (Агапов 1959: 22, 30).

The 1960 s saw the emergence of a core group of artists and filmmakers who fought passionately for changing the trends of the Stalinist era. They were given the name шестидесятники (the Sixties generation). They were the 'products' of Khrushchev's reforms: the expansion of civil liberties, improved standards of living, consumerism, opening up to the world (Dumanciić 2010: 10).

The documentaries of those years began to focus on the industrial sector and portray working people. Work also becomes a topic for journalistic analysis and poetic reflection. A wide array of genres was suggested, from reporting to allegory. Filmmakers became concerned with mundane issues and rooted for the heroes as they solved their problems (Джулай 2005: 143). Work was viewed as a creative act, just like art (Джулай 2005: 173).

The newspaper editorials were also expected to churn out stories on the lives of collective farmers and workers. According to Tiiu Kreegipuu, along with the brave revolutionaries and noble leaders, simple working folk also qualified; they were portrayed as "people who devoted themselves to bringing benefit and fame to the collective in a self-effacing manner' (Kreegipuu 2015: 190). At the same time, it was emphasised that the domination of the collective over the individual was a prerequisite for qualifying as the new Soviet Man. The interests of the state, the Communist Party and the general public always took precedence over personal interests. If necessary, Soviet propaganda was ready to create and mythologise heroes. Nevertheless, this allowed journalists to employ a more humane approach and a more humanistic style of portrayal (Kreegipuu 2015: 190, 191). Journalism and documentary film went hand in hand in the Estonian SSR. In addition to the fact that both were viewed as mass media, many journalists also wrote scripts for documentary films. ${ }^{11}$ According to Elmanovitš, the documentary is a descendant of the informational genres that 'lies on the border of reflection of nonartistic and artistic life' (Elmanovitš 1977).

The Soviet Union was always constructing the new Soviet Man, an ideal that did not exist and whom the ruling ideology used for devising a community that was to be called the Soviet nation. Constructing a national identity also means constructing a sense of community, according to Nichols. Shared values and beliefs are essential for the way society perceives (Nichols 2001: 141).

'It is the mission of the contemporary Soviet cinema to portray the building process of communism, whereby the builders themselves are transformed, giving rise to a new communist individual,' wrote the film historian Alexander Karaganov in 1959. 'People's enthusiasm for work is constantly growing in socialist society; the moral incentives for work are becoming ever more significant' (Караганов 1959: 40, 42).

Karaganov, along with his colleagues, verbalised the grand illusion of the official ideology. It included the notion that documentary film belonged to society in the Soviet Union and that each citizen was burning with the wish to take part in it. According to Lyudmila Dzhulai, the Soviet cinema of the 1960s could be called the cinema of belief - belief in the Soviet structure, belief in the nationally celebrated mission of cinema and belief in the best possible audience, who were capable of appreciating and understanding the artists' work (Джулай 2005: 112). Cinema provided millions of Soviet spectators a specific perspective or framework for interpreting daily experiences, analysing modern innovation and seeing reality in a new light (Dumanciić 2010: 8). Up until the late 1960s, when television took over, films were the main factor that shaped how people thought, fantasised, interpreted their past and constructed their future (Woll 2000: xii).

11 The National Archives of Estonia, Protocols of the Party meetings at the Tallinnfilm studio (24 January 30 December 1968), ERAF.86.1.321, p. 57. 
The Thaw introduced the term "problem films' into Soviet cinema vocabulary. As the Tallinnfilm studio of the Estonian SSR had to submit its content plans for approval to Goskino ${ }^{12}$ in Moscow, there could not be significant deviations from the general trends in the Soviet Union. At an expanded Communist Party meeting at the Tallinn Film Studio on 19 February 1962 it is announced that one critical newsreel is to be produced each month. ${ }^{13}$ A section titled 'Where's the switch?' is added to the Soviet Estonia (Nõukogude Eesti) newsreel (Mesila 1972: 64). This is how Raivo Rammus, the editor of the newsreel department, described the department's principles to his colleagues at a public meeting of Tallinnfilm's Communist Party organisation on 24 September 1968:

In our view, the primary function of our studio's documentary films is the social study of our time and our society. We welcome problem films, ... [where] the resolution of the subject matter entails something more than just information or illustration. ${ }^{14}$

From Stalin's death until the mid-1960s, biting social criticism dominated in Soviet literary works, which were typically published in the monthly literary magazine Новый мир. 'The prevailing perception was that the story must be against something' (Bezzubov 1977). In 1962 Aleksandr Solzhenitsyn published his ground breaking One Day in the Life of Ivan Denisovich (Один день Ивана Денисовича) that was translated into Estonian in 1963. Apparently, the publication of this book showed that the threshold for the ideological tolerance of social critique had increased considerably.

However, this did not mean that creative prohibitions and restrictions were completely lifted. Far from it. Censorship and self-censorship were still very much in force. Some subjects simply could not be broached directly. There was no tolerance for explicit systematic criticism of contemporary Soviet society or for a complete questioning of the Stalin era. The relations between Leninism and Stalinism were also taboo. These kinds of topics could only be mentioned in passing or hidden between the lines (Woll 1993: 11). While the doctrine of socialist realism had lost most of its power by the 1960s (Woll 1993: 3), the official party line stayed true to it. Khrushchev asserted this stance at a meeting between party and government leaders and writers and artists in 1963:
Our nation needs art that is com- bative, revolutionary. Soviet litera- ture and art must portray the great and heroic era of building com- munism vividly and memorably, reflecting truthfully the entrench- ment and victory of new commu- nist relations in our lives. The artist must be able to see the positive and rejoice in this positivity, which is the essence of our reality; the artist must sustain it. At the same time, we must not disregard the negative aspects; everything that obstructs the new from springing up in our lives. (Hruštšov 1963)

Nevertheless, by 1963 the processes of the political Thaw had reached the point where artists not only ventured to the periphery of official artistic expression, but also criticised the socialist realists publicly, calling them naturalists and sugar-coaters of reality (Hruštšov 1963). The main source of encouragement and enthusiasm had been provided by General Secretary Khrushchev himself, when he had condemned Stalin's cult of personality in his speech delivered at the 20th Congress of the CPSU (1956). ${ }^{15}$

The 20th CPSU Congress had a major impact on the development of film, and, according to the contemporaries, eliminated the obstacles that had hampered the development of cinematography. 'Already the first films showed that our film staff are able to solve complicated creative tasks and create works with great heroic resonance' (Баскаков 1964: 36). 
Somehow, it became acceptable to use the Stalin era for portraying Soviet reality in dark colours, while the official ideology demanded a positive depiction.

The CPSU General Secretary was resolute in his positions and robust in his choice of words:

Whatever curse words might be used for damning the works of the artists of socialist realism and however the abstractionists and all other formalists may be lauded, any person of sound mind can clearly understand that the former are real artists making real art, while the latter are individuals with distorted tastes whose screws are loose, in a manner of speaking, and who produce vile trash that insults people's feelings. (Hruštšov 1963)

Khrushchev labelled the artists who had renounced socialist realism formalists and abstractionists whose art was not understood by the people because of its remote and obscure ideas. Neither did Khrushchev tolerate artists finding inspiration in Western art; quite the opposite - even passivity was impermissible, as 'Soviet art functions in an ideological framework', peaceful co-existence was out of the question. The General Secretary also condemned the tendency to paint the entire Stalin's era in extremely dark colours.

However, it should be noted that by straying from the mainstream, the authors set out to optimise the existing structures rather than discredit the ruling system (Dumancić 2010: 10).

After the Prague Spring of 1968, the enthusiasm of the 1960s for 'humanising' heroes began to wane, leading to a standstill. The observational genre that had become popular in the 1960s 'reverted to the ceremonial style and turned into a filmic document-monument' (Джулай 2005: 142). Problems were recognised nominally, by just stating what worried, helped or disturbed the 'hero' - the individual, the collective, the kolkhoz, etc. The position of the author had no place in this approach (Джулай 2005: 183).

According to official rhetoric the nation had reached high socialism by the 1970s, but cinema was still tasked with depicting 'the maturing of the socialist personality - the new Soviet Man'. Film scholars of the time expected the inner transformation of the hero to be a deep, dynamic and convoluted process. Professional achievements and a rich inner life were equally important (Власов 1974: 1). Positive pathos could be expressed within the mundane that lacked exceptional sudden and dramatic breakthroughs, provided that the heroes' conduct during the decisive moments revealed their mental substance and moral beauty (Власов 1974: 5).

In Tallinnfilm's production, the mid1970 s is considered to be a period of more active involvement with social problems (Anonymus 1983a: 30). For example, at the 1977 annual gathering of Estonian, Latvian and Lithuanian documentary filmmakers in Kingissepa (Kuressaare), Tallinnfilm presented ten films, half of which were problem films (Elme 1977). Meanwhile, the situation of narrative cinema during the same period was rather different according to critics: 'Instead of artistic reflection of the reality of life, they copy it with simplified methods of artisans' (Elmanovitš 1976).

According to Dzhulai, Soviet documentary cinema faced a deep moral crisis by the early 1980s. Many masters of documentary had found a cosy home in the system and only a few portrayed the social slump: economic stagnation, mental impoverishment, and tension in the environment. This was usually done cautiously (Джулай 2005: 178). By contrast, in Estonia socially critical films were released one after another in the beginning of the 1980s: Fool the Field Once... (Narri põldu üks kord..., Enn Säde, 1981), Tiredness of the Ploughman (Künnimehe väsimus, Enn Säde, Jüri Müür, 1982), ...And Soup Is Ready in Time (...ja supp on valmis õigel ajal, Valeria Anderson, 1983), Hay Time (Heinaaeg, Enn Säde, 1984), Lasnamäe (Mark Soosaar, 1985). 


\section{CIRCUMSTANCES IN ESTONIA COMPARED TO THE REST OF THE SOVIET UNION}

The Estonian SSR was one of the last three republics to be annexed to the Soviet Union. The annexation was violent, followed by merciless repressions. Therefore, it was unreasonable to expect that the majority of Estonians would show enthusiasm for 'developing the new Soviet Man' or 'cheering on socialist progress'. The film industry was also in a repressed state, staffed mainly with subservient film administrators sent from Russia.

In Estonia, the cultural field was shaped mainly by the recording of history and figurative art, and as of the 1960s, also theatre and film. In the early 1960s, directors who had recently graduated from the VGIK joined the Tallinn Film Studio and proceeded to adapt national literary classics for the screen. Documentary film also experienced a shift: the local staff turned to national topics in addition to the compulsory subjects (Västrik 2015).

The only way to touch the emotional chords of national identity without contradicting ideological taboos was to shift to the poetic mode. It replaced the rational representation of the surrounding reality with the use of images, archetypes and innuendos. In the Estonian SSR, this meant that the heroes and landscapes that used to represent Estonian national identity before the Soviet occupation were revived in the form of contemporary equivalents that conveyed the same principles as best they could. As a result, directors turned to locations that the official ideology considered to be the abandoned back-country, but the appearance of which had remained unchanged during the Soviet era. The new heroes were men stubbornly battling the land or the sea, but at the same time, living in harmony with nature (Västrik 2015). Admittedly, this was not an exclusively Estonian trend; there were others in the Soviet Union who made films about their respective ethnic traditions (Джулай 2005: 161).

\section{VALERIA ANDERSON}

Valeria Anderson (born in 1932) studied to be a narrative film director at the VGIK as a student of Mikhail Romm and graduated in 1959. Her diploma film, Encounters in the Street (Kohtumised tänaval, Estonia, 1960), won first prize at the annual convention of Baltic and Belarusian documentary filmmakers and this provided great impetus for the young director. After having realised that it was almost impossible to find work in narrative cinema (Tallinnfilm produced only one or two narrative feature films annually), she reoriented herself to documentary film. She made 29 documentaries during her career that spanned 30 years.

Anderson was a member of the generation of filmmakers that was sent to Moscow by the republican authorities, so that they could return after graduation and 'help put the provincial film industry on its feet'. Several other directors ${ }^{16}$ joined the Tallinn Film Studio (later Tallinnfilm) at approximately the same time as Anderson and began advocating the innovative ideas they brought with them from Moscow at the local studio, which was still operating under Stalinist principles. ${ }^{17}$

Anderson had mastered editing techniques ${ }^{18}$ and was in love with Italian neorealism. Unlike Andres Sööt, Peep Puks, Peeter Tooming or Ülo Tambek, Anderson did not yearn for Estonia's 'long-lost days of glory', but instead opted for putting her skills and talents to work in the service of the progressive Soviet documentary discourse. At the studio, this placed her between two opposing sides: the inert adherents of socialist realism and her nationally inclined colleagues. By making films about modern heroes, she could channel the shortcomings afflicting society.

\footnotetext{
16 Jüri Müür, Leida Laius, Veljo Käsper; from the Lunacharsky State Institute for Theatre Arts (Государственный институт театрального искусства им. A. В. Луначарского, GITIS): Kaljo Kiisk, Arvo Kruusement, Grigori Kromanov.

17 Author's interview with Valeria Anderson, 29 March 2011.

18 Lev Kuleshov's wife Alexandra Sergeyevna Khokhlova was Anderson's professor of editing at the VGIK.
} 


\section{SOCIOCRITICAL FILMS BY VALERIA ANDERSON}

Below, I will analyse three documentaries by Valeria Anderson that portray workers fulfilling their daily tasks as well or as poorly as the circumstances allow. I will focus on how the heroes are constructed, how problems are depicted and how the culprits are discovered. To that end, I will describe the text of each film, both verbal and filmic, and compare it to the Soviet (documentary) discourse described above. I will look for archetypal patterns and metaphors justifying the motivation of the heroes' actions.

\section{HELLO, GIRLS!}

\section{(TERE, TÜDRUKUD!, 1962)}

Hello, Girls! (Figures 2-4) tells the story of how members of the Komsomol from the town of Narva are sent to work in the fields. From the first scene, we can tell that this is being done at the instructions of the Communist Party, as the bus transporting the young people is decorated with a corresponding slogan.

The film is basically a group portrait filmed in the course of an agricultural season. The voice-over text was written by the studio (Ülo Tambek) and narrated by students studying at the film studio. This makes everything sound overly theatrical. It is as if the girls were looking through a photo album and expressing enthusiasm and joy when recognising familiar scenes.

The film is obviously staged and the imprint of the ceremonial pathos of the previous era is very apparent: we have the smiling tractor driver; people start to work by spitting in their palms; the low points are overcome by starting water fights, etc. But the setting is real, the young members of the Komsomol are real, and the nature, which only produces rain, is real.

The youngsters are put up in a building with a leaky roof, peeling paint on the walls and no water in the faucet. By unanimous decision, the culprit is the manager of the sovkhoz, who 'does nothing to improve the living conditions'. It is also the manager's fault that the boys are sent to pick rocks, 'which is tedious and teaches them nothing'.
The manager also seems to be at fault for the rainy weather. We see men shovelling dirt, with the manager standing in their midst looking like a scapegoat. We can also see that the urban youngsters have never worked the land and look helpless.

Still, the work gets under way. The machines are started up and the young women are eagerly shovelling dirt. After a while, cracks begin to show in their enthusiasm. At first, a man runs off without warning (his name is mentioned in the voice-over and actually seen on an envelope). This act is candidly condemned in the voice-over text. Next, three girls submit their letters of resignation. A general meeting is called to convince them to stay, but the quitters remain defiant, challenging the authority of the sovkhoz in a major way. 'What can we be proud of here?' the most rebellious girl asks. She seems to be encouraged by the presence of the camera, while another girl, who is shier, covers her face with her hands to hide it from the camera.

The voice-over commentary seems to be compassionate toward the quitters and does not condemn them, as would certainly have been the case a decade earlier. 'At least they made the manager think.' A panoramic shot features the back of the bus leaving and the girls hoeing in the rain. This clearly demonstrates 'the spontaneity of it all'.

From that moment on, the filmmaker's attitude towards the manager changes. With a heavy heart, he signs his letter of resignation, and sends men from the sovkhoz to replace the roof and windows of the youngsters' lodgings. He mobilises the entire staff to rescue the drowning crops. The voice-over attributes all these acts to the manager personally. In the finale, when it is time to dream of a future youth sovkhoz, the manager steps into the deserted dorm room filled with wire beds, and gazes into the distance with the gaze of a 'genius strategist and leader'.

The moralistic lines, 'You are also invited to our sovkhoz. Come, and you will not regret it', are followed by a shot of storks flying south in a triangle formation. Anderson 
has given the following assessment of the events: "I thought for the longest time how I would finally say this; I didn't dare to just come out and say it. I showed the gravity of it all and then I thought, how do I end it? How do I put it into words? And then I thought of those migratory birds...'

Hello, Girls! was an 'appropriate’ film for its time. The party sent the Komsomol members to the country to make a contribution to agriculture. And the youngsters obeyed, despite the difficult living conditions and the weather. While the film is didactic, it is not as ideologically harsh as the purely socialist realist films. The heroes are made of flesh and blood and also experience moments of weakness and resignation. The manager was able to create an atmosphere of enthusiasm characteristic of the era: people confront the difficulties with smiles on their faces; and in moments of turmoil, they sulk at the 'right' moment in terms of framing and composition, etc.

The director's handwriting finds its main expression in the editing technique. The director guided the filming of Hello, Girls! The characters are prompted by the crew, making it possible to create a storyline and intertwine connotations through narrative editing: people glancing out of windows while something significant is happening outside; panoramic shots of those who are leaving and those who are staying; small moments when the camera 'happens' to be in the right place.

The social criticism is limited to revealing the difficult living and working conditions at the sovkhoz. The culprit is the manager of the sovkhoz, who is completely redeemed by the end of the film. His final score is positive and the film is summarised by the ideological metaphor of him gazing into the distance where the future awaits.

The director does not dare to directly criticise the party campaign of sending young urbanites to work in the fields, although she supposedly questioned the sustainability of the project. "How many of them were there to stay? That was not why they went. The place was just close to Tallinn, convenient for running off to other destinations.' She hid her opinion of the campaign in the metaphor of the migratory birds. Two contradicting metaphors essentially exist side by side.

\section{WEAVERS (KETRAJAD, 1976)}

Weavers (Figures 5-7) contains no staging. However, the ideological catalyst is again the wish to accommodate the Communist Party.

In 1976, six women from the Balti Manufaktuur textile factory committed to achieving the greatest assignment in the Soviet Union on their pneumatic spinners. 'We decided to transfer from 4.5 machines to 6 machines as a present in honour of the 25th Congress of the CPSU,' one of the weavers explains. She continues with a pathos that was already rare by the 1970s: 'During the days leading up to the congress, would it be enough to just settle for what these magnificent machines had already achieved? Of course not.'

The film conveys the manic rhythm generated by the six spinners. The camera jumps from the weavers running amid the rows of machines to the shuttle and rolls of thread. The editing is quick and transmits the stress of rushing. Initially, the heroines handle the situation confidently.

During three months the factory has received low-quality cotton, and half the weavers give up. The camera creates a strained atmosphere, by moving subjectively to the machines, hands and faces. Close-ups alternate with long shots, everything is in motion. The weavers work like dervishes. Inhuman. The editing generates a super-fast pace.

An unexpected expert, in the person of a cloakroom attendant, announces that it is no easy task running around for eight hours, and that three spinners would have been enough since the thread is of such poor quality.

Like in Hello, Girls!, the dispute ends up in the manager's meeting room. The weavers are courageous, the manager quibbles.

The weaver who had declared the wish to exceed expectations in honour of the congress, stays true to the party rhetoric: 

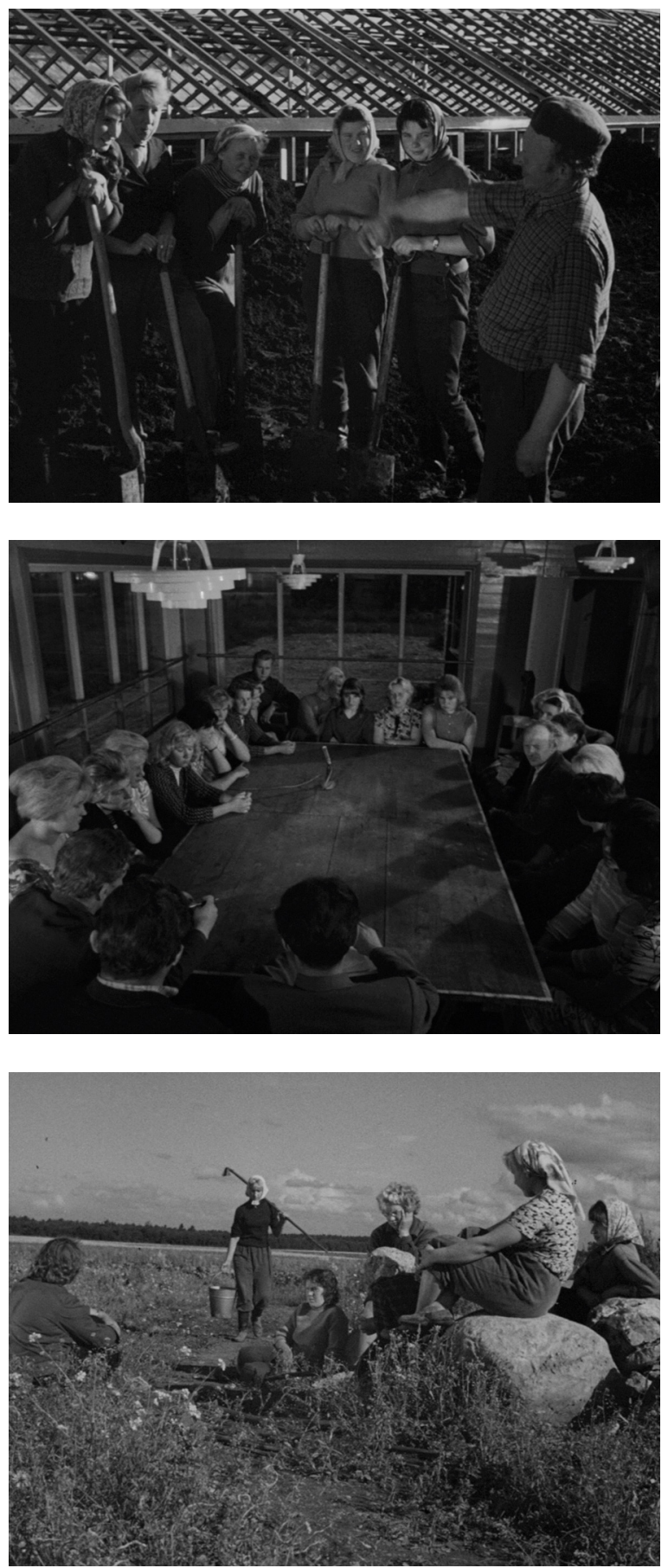

FIGURE 2-4. Valeria Anderson, Hello, Girls! (Tere, tüdrukud!, Estonia, 1962). 
'This five-year period is focussed on quality. I look at these bobbins and my heart breaks. It's unbearable. Before, I used to feel a certain satisfaction at the end of a shift, but now there is absolutely none.'

The manager promises to solve the problems, and the weavers are encouraged to stay true to their commitment. However, the situation does not improve and the women are forced to back down from their commitment.

The cloakroom expert speaks again, and referring to a Russian proverb, describes the failure to meet the commitment made to the Communist Party: 'Once you've taken something on, don't go looking for excuses.'

The situation is summed up at a gettogether. A vodka bottle is passed around. The women analyse what has happened and decide it was a rape of the organism. They admit that it was nice to receive a significant raise in salary, but most of all, it was a pleasure to be better than the others.

The final shots take us outside the textile factory for the first time. Initially, the camera lingers on the blossoming apple trees in front of a concrete apartment building, followed by an overhead view of the block of apartment buildings.

What made those simple women workers aim for the impossible? Probably a hunger for fame and, to a lesser extent, financial gain. A simple weaver can suddenly become a media star. This required delivering a vulgarly pro-party text, which very few people would take seriously in the Estonian SSR of the 1970s. The idea of making a present for the congress was incomprehensible to most people. ${ }^{19}$ These lines were recorded at the wish of the director. What was her motivation in doing this? Either a sincere wish to record the impetus for the women's superhuman endeavour or the intention to ridicule the entire venture by using excessively moralistic (and therefore

The citizens of the Estonian SSR were also very well aware of the holidays that enabled 'money to be pumped' from the system. Lenin's birthday and the anniversaries of the October Revolution and the Great Patriotic War were always a good justification. not credible) rhetoric. Judging by the tone of the rest of the film, we can surmise that the director's intentions were sincere. This was not an aberration, as the mass media sang the praises of socialist working heroes all the time, and The Weavers was just remaining true to the canon. According to Elmanovitš, the weavers were motivated by the need of the self-realisation, by the understanding of and belief in the communist work ethics (Elmanovitš 1977).

Communist rhetoric led a life of its own, without any help from the people. It is also significant that, of the six women who joined the campaign, only one was Estonian. Estonians were generally known to be much more sceptical of communist rhetoric than Russians.

If it is true that the director was sincere, the role of the cloakroom attendant needs further explanation. In this case, side-line commentary is provided by a person who is insignificant in the social hierarchy, possibly representing the archetype of the sage or aqsaqa ${ }^{20}$, i.e. someone who knows more than is expected of their position and whose opinion matters. The attendant's assessment of the failed heroines is surprisingly critical. It suggests that the failure might not be the management's fault after all. Quite possibly, the heroines who had offered to step into the limelight were the ones who did not have what it took to get the job done.

Elmanovitš was also surprised by the cloakroom attendant's appearance on the screen. In her opinion, this was a loan from traditional dramaturgy that was almost never been used in documentary film. She points out that this is 'a lyrical or romantic re-telling of the main storyline with a humble, playful style, which at the same time grounds and broadens the main storyline, making it concrete and giving it new meaning' (Elmanovitš 1977).

Just like in Hello, Girls! the main culprits responsible for the weavers' troubles are in management. The good workers want to honour the congress with record results,

A revered male elder in Central Asia. 

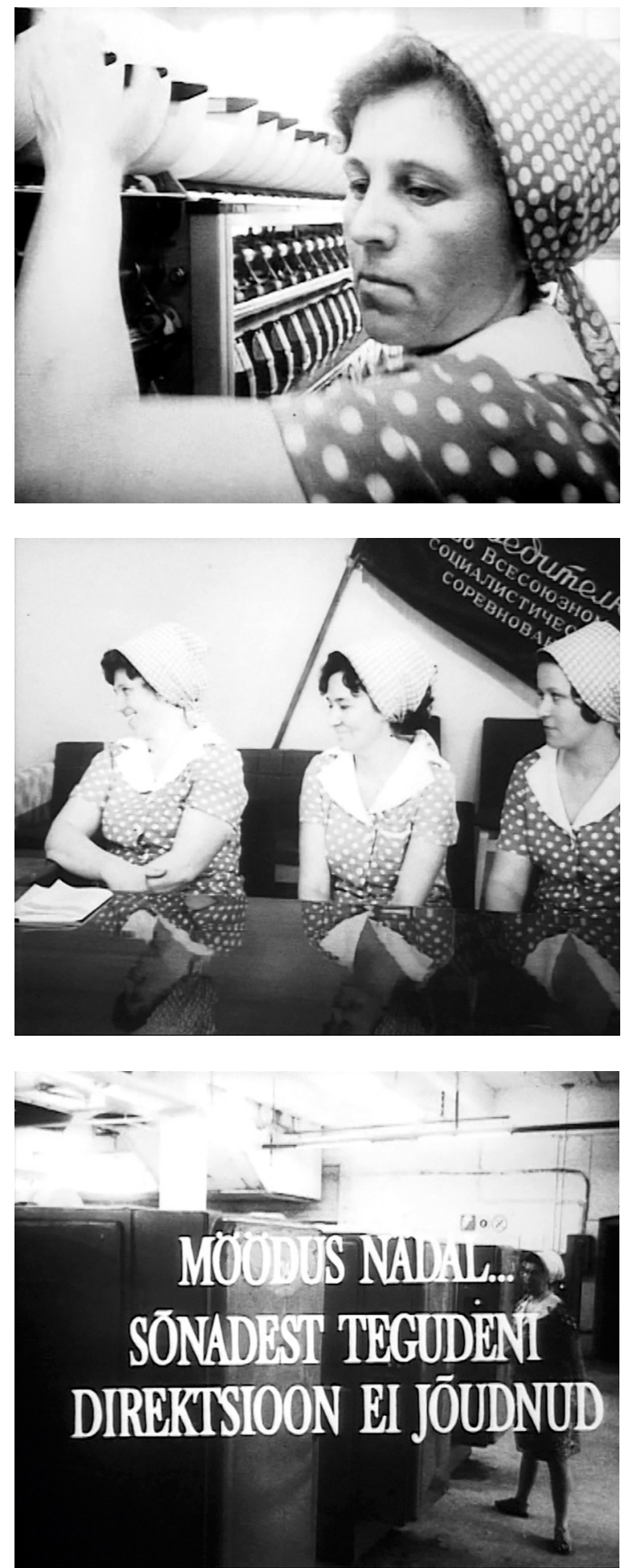

FIGURE 5-7. Valeria Anderson, Weavers (Ketrajad, Estonia, 1976). 
but the management provides low-quality raw material. There is no further elaboration of this issue, as that might lead to the conclusion that the entire Soviet Union is in disarray, which is actually the reason that defective thread was delivered to the factory. The management makes promises and then evades responsibility, what else can they do?

The hero's human dimension is revealed in the final episode - at a get-together. This is where the various personality layers are peeled back. While a Russian proverb warns against letting fists fly once the fight is over, this is exactly what the women do, giving the viewers insights into their motivation. Digging deeper, it might seem that socialist competition itself is being scrutinised.

The final shot of the blooming apple tree brings to mind a song that was popular in the Soviet Union, titled And Apple Trees Will Bloom on Mars (И на Марсе будут яблони uвecmu, melody by Vano Muradeli, lyrics by Yevgenia Aronovitch), and symbolised man's omnipotence in outer space. The shot may have enchanted the director with its beauty, but maybe it was a conscious metaphor: we are dreaming of populating Mars, while being incapable of delivering quality cotton.

The block of concrete apartment buildings is a clear symbol of the Soviet attitude toward ultimate development: a state governed by the dictatorship of the proletariat where everyone lives in 'urban' settlements, whether in the interior of the country, in the tundra or by the sea. 'The new urban space ... would become the "material and technical basis" for communism ..., preparing the ground for the citizens' ethical and political enlightenment, economic well-being, and the ultimate assertion of a progressive consciousness' (Oukaderova 2017: 8). In literary poetics, descriptions of nature and landscapes are major tools used by authors to convey the basic ideas of work (Vaino 2016: 83). Eva Näripea has come to the same conclusions in terms of film poetics (Näripea 2011).
The Art Council at Tallinnfilm awarded the The Weavers the highest category²1. There were a multitude of compliments. Leo Ilves, the deputy editor-in-chief of the creative unit for newsreels, documentary and popular scientific films, highlighted the topic of the film, subject matter and issues. The comments of Enn Rekkor, the deputy director of the studio, and Ülo Tambek, the director, about the nature of socialist competition, based on the example of The Weavers, reveal how the so-called 'ideological workers' actually perceived socialist pathos. In the words of Tambek: "From this we can understand that such a socialist competition is nonsense, under conditions where the people who work at the machines have no way of doing what was promised and also are not provided any information.'22 According to Rekkor: 'The film shows that if we resolve socialist competition as shown in the film, we will not resolve these tasks and the socialist race will lose all its meaning.'23

A year later, in 1977, The Weavers was awarded second prize in the short films category at the 10th All-Union Film Festival in Riga. Thus, revealing the dark side of socialist competition was, for all practical purposes, accepted at least among the filmmakers.

\section{...AND THE SOUP IS READY ON TIME (...JA SUPP ON VALMIS ÖIGEL AJAL, 1983)}

The most famous documentary by Anderson, ... And the Soup /s Ready on Time (Figures 8-11), is her sincerest, most immediate, most critical and also an entertaining film. It also most poignantly conveys the idea that heroic acts can resolve any shortcomings. Nothing about the $\mathrm{V}$. Klementi

\footnotetext{
21 According to the system of classification that existed in Soviet film industry. This included 'five categories: highest, one, two, three and four. The categories influence[d] the decision-making process that fixe[d] the number of copies to be distributed'; it also determined the amount of premiums paid to filmmakers (Golovskoy, Rimberg 1986: 47).

22 The National Archives of Estonia, ERA.R-1707.1.1506, pp. 84-85.

23 The National Archives of Estonia, ERA.R-1707.1.1506, p. 86.
} 

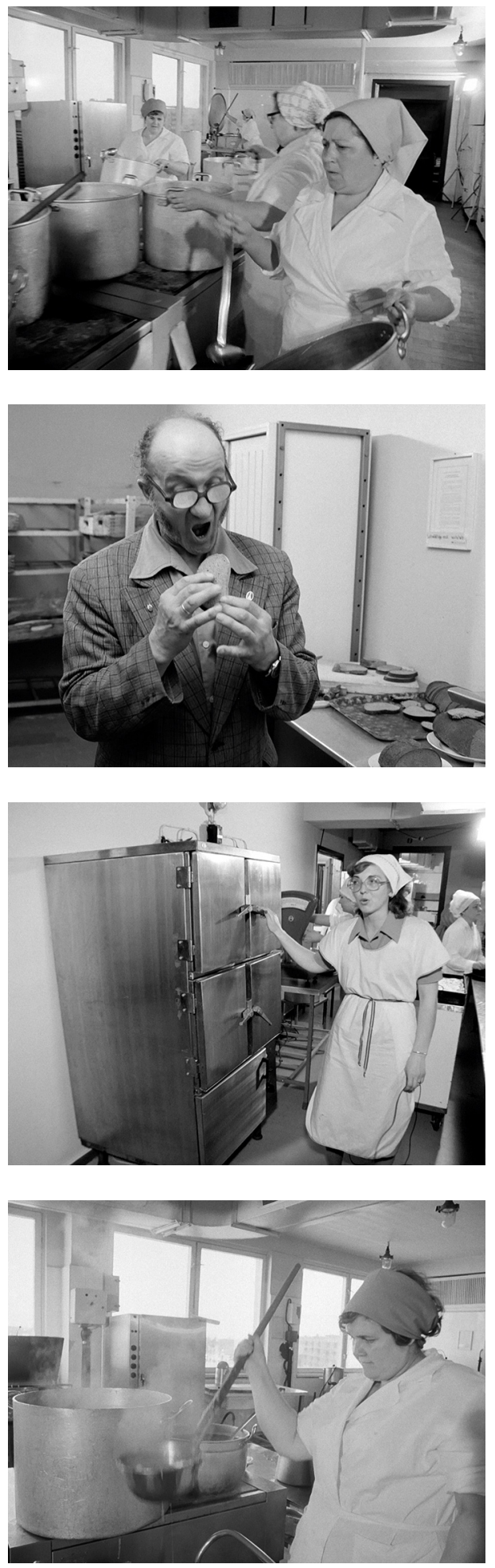

FIGURE 8-11. Valeria Anderson,

...And the Soup Is Ready on Time (...ja supp on valmis öigel ajal, Estonia, 1983). 
sewing factory cafeteria gives us reason to believe that lunch will be served on time; nevertheless, it is and the people get fed.

While the film is a collective portrait of the cafeteria staff, it also has several clear protagonists: the electrician/lifeguard, the merchandise expert and the manager. The film crew do not conceal their presence or the filming process. This is indicated in the opening shot, which shows the director Anderson sitting on the beach together with the lifeguard/electrician. Anderson keeps appearing in the shots, chopping cabbage with the cooks, and tasting the soup with the workers. We can also hear the director of photography Arvo Vilu interacting with the characters.

In summary, the film tells the story of a workers' cafeteria, where the resourceful staff manages to serve lunch on time every day, despite delivery problems and broken machinery. And it is not just any lunch, but also a tasty one.

The main keys to the film's success are the wonderful rapport between the crew and the characters, the charismatic stars among the cafeteria staff and Anderson's trademark - masterful editing. Almost all the dialogue in the film occurs in real time: while the cooks are preparing food, the electrician is repairing or presenting the equipment, the cafeteria manager is presenting the technology. Even the merchandise expert, while sitting at a table, is part of the action and in constant telecommunication with the antagonists. Anderson uses parallel editing throughout the film: one monologue or scene is presented in several cuts, alternating with another monologue. This creates tension and the impression that the action is lasting longer than it actually does.

The film's 'classic' scenes feature the Estonian cook, chatting away about the diners' demands while mixing the Estonian and Russian languages. The sincerity, naivety and candour are astonishing. The entire film is playful, and opens and closes with musical numbers by the cooks.

The merchandise expert's attempts to secure her 'rights by phone' are divided into eight episodes; the lifeguard/electrician appears in the kitchen five times, the young cafeteria manager four times. They are all conscious of the camera. The merchandise expert is clearly emboldened by the camera and gradually becomes more aggressive toward those at the other end of the phone.

What criticisms does the film present? The raw ingredients are spoilt, with up to 50\% being discarded; milk deliveries are late, or they never arrive or they get mixed up. The Soviet technology is not fully operational, fails to function from the very beginning or keeps breaking down; the maintenance company is unresponsive to the cafeteria's complaints.

While chopping cabbage, the cook explains that, although there is no allowance for wastage, almost half of the raw ingredients are wasted. 'And that's why the soup is thin.'The cook's Russian-speaking colleague complains: 'There is lots of responsibility and many expectations, but where are the raw ingredients? Tricks won't do; we try to make everything taste good.'

The electrician/lifeguard repairing the steamer explains: 'Actually, this isn't even my job, but what can you do? The maintenance people are in no a hurry to help with our kitchen. If they get here, fine; if they don't, also fine. But people want to eat. Not helping would be out of the question.'

The cafeteria manager demonstrates a steamer that has never worked properly. 'Let's see if we can make this Finnish steamer work, then we can sell this one.' Turns out that broken equipment can still be sold. There was no reason to hide the fact that Finnish technology was more reliable. The manager also proudly presents an oven made in Finland - one of the few kitchen appliances that works perfectly.

The director asks the young cafeteria manager how she manages it all and gets an unbelievably politically correct answer: 'I want to hope. More than anything, I must say that l've been extremely lucky ever since I came here; especially in terms of the staff at the Klementi sewing factory, those in all the service units, and of course, our own management. So, it's my hope that with 
these experienced and seasoned comrades by my side, l'll manage it all somehow.' 'What if you can't manage?' asks the director. 'I still want to remain optimistic,' answers the manager.

Does the situation make anyone despair? No. Only the merchandise expert is speaking ever more loudly, but clearly because the camera is present, and her main source of irritation is that even the arrival of the media is not helping matters. Most of the others approach the situation with humour, doing what they can, but it is obvious that the chaotic state of the entire country is old news and not a taboo topic for anyone. This probably consoled the cooks as well: how dissatisfied could the clients really be; everyone knew about the rampant dysfunction in the country. People just voiced their indignation and made fun of the chaos together. The Soviet Union was rife with anecdotes about the mayhem and outright stupidity fostered by the state. One thing is certain: nobody is about to jump ship, even though the system is of no help in meeting the official commitments. It is considered natural for individuals to make a special effort. At the same time, it always provides an excuse if the result is not $100 \%$ - it was the best we could do under the circumstances.

...And the Soup /s Ready on Time also received the highest category from the studio's Art Council. Raivo Rammus, the head of the newsreel department, even argued that it was the most optimistic film about contemporary topics thus far. 'Men and people can rise above the disorder.' Vello Kallaste said that the goal of the film showing how a forward-looking team had to struggle, rather than work - was achieved. Leo Ilves found that Anderson had become a humourist. Satisfaction with the film was unanimous. ${ }^{24}$

\section{CONCLUSION}

True to the canons of socialist realism, Stalin's regime produced whitewashed heroes pp. 60-61. who lacked humanity. This did not satisfy the artists or the citizens, who longed for heroes of flesh and blood, complete with human deficiencies. While constructing such heroes it became clear that society itself had deficiencies, which the heroes then confronted.

In all three films, the crew is always on the side of the heroes. They are rooting for the birth of the hero. As shooting begins, they are not sure whether the characters will be able to prove them as heroes, and setbacks do occur in the first two cases. At the same time, in these films Valeria Anderson clearly wishes to construct heroes out of simple workers. This was expected of her by the official system, but also supported by the studio management. Therefore, the director was working 'on solid ground'. Her task was to add a human dimension to the heroes, and this was the measure of her success as a filmmaker in the eyes of the system.

The female heroines are fully-fledged characters with their own agendas who are not playing a supporting role to patriarchal men. In all of these films, it is the men who are playing the supporting roles. Thus, Anderson is free of the Stalinist notion of masculinity, according to which superheroes were the ones who resolved all situations. This also applies to Hello, Girls!, the earliest of the three films, which has a script that otherwise contains much of the overthe-top optimistic rhetoric of that earlier period. The fact that a female director was making films about female heroines distinguishes these films from the rest, but it is not enough for labelling Anderson as a feminist. Her filmography also contains many documentaries with male heroes, who are accorded the same empathy as the heroines of the films discussed in this article.

The specificity of the era allowed for the depiction of aberrations from the ideal: leaky roofs, volunteers quitting, inferior thread, etc. Showing the errors inevitably raised the question, 'who is at fault?'. Someone had to be blamed for the disarray. For Anderson, the culprit was found in a higher authority, i.e. a manager or the supply 
unit. According to the established canons, this kind of 'guilt' was not a deadly sin, but could be considered to be a human error that did not preclude a positive outcome, as is the case with the manager in Hello, Girls! The articles on documentary film emphasised the need to portray human imperfections as a tool for increasing the credibility of the characters. The heroes needed to have inner strength and beauty, but the stories were helped by not constantly focusing on this.

While Hello, Girls! is still teetering on the border between socialist realism and new documentary journalism,...And the Soup Is Ready on Time and Weavers definitely represent documentary journalism in which we can identify director's handwriting. This is mainly reflected in the editing, which creates an atmosphere of anxiety. The same anxiety is palpable among the spinners and soup kettles. The repetitive portrayal of similar activities creates a narrative rhythm, skilfully manipulated by the director to increase the tension and make the viewers identify with the characters on the screen. This makes the designed message more likely to reach the recipient, i.e. the audience.

In ... And the Soup /s Ready on Time, the director herself joins the action. This creates a warm relationship between the crew and the characters and produces information that criticises the entire ruling system. The system is not explicitly identified as being the Soviet Union, a synonym for the socialist system - this was still punishable in 1983 - instead, the criticism is targeted at a single industrial sector. However, only the ministry and the party are above this level, so ultimately this means the USSR.

The new documentary discourse that had begun with the Khrushchev Thaw seemed more honest and sincere, and above all, more realistic to both the artists and the audiences. At the same time, ideological vigilance was still very present in society; and mainly driven by self-censorship, the authors learned to write between the lines, and the audiences to read between the lines.
In broader terms, all film production can be viewed as writing between the lines: in order for some authors to be able to experiment with creative and ideological innovation, others produced heroic tales that pleased the 'system'.

There were no limits to the genres of the heroic tales. They could take the form of reporting, poetic observation or documentary journalism. After having boomed during the Khrushchev era, social criticism was again stifled during Brezhnev's reign. In the 1970s, the CPSU declared that the Soviet Union had reached advanced socialism. We now know that the giant country had fallen into stagnation by that time. Paradoxically, from the mid-1970s until Gorbachev's ascent, Tallinnfilm released many socially critical documentaries. By that time, the filmmakers who had started their career in the 1960s had matured, enough time had passed since the Stalinist repressions and they dared to take risks. Moreover, as the success of The Weavers at the All-Union Festival demonstrates, social criticism was officially recognised. Heroes were needed, but so were guilty parties. Almost anyone could be blamed, except the Congresses of the CPSU and the regime itself. Documentary makers understood this and expanded the playfield. 


\section{REFERENCES}

Агапов, Борис 1959. 'Новый человек на экране'. Искусство кино 6, 21-30.

Andrews, Tom 2012. 'What Is Social Constructionism?' Grounded Theory Review 11, 1. http://groundedtheoryreview.com/2012/06/01/what-is-social-constructionism/ (11 October 2017).

Anonymous 1962. 'Filmitöötajate kongressilt'. - Sirp ja Vasar, 21 December.

Anonymous 1983a. 'Tõsielufilm ajapeeglis. Ring-

küsitlus'. - Teater. Muusika Kino 4, 25-33.

Anonymous 1983b. 'Filmikriitika preemiad'. - Sirp ja

Vasar, 1 July.

Ansip, Karol 2006. Ülevaade Eesti dokumentaalfilmi arengusuundadest autorifilmi tekkeni. Autorifilmi näide Andres Söödi loomingu põhjal. MA thesis. Eesti Humanitaarinstituut. Tallinn.

Ansip, Karol 2013. 'Eesti tõsielufilmi oma lugu.

Põhijooned ja eripära kuuekümnendatest taasiseseisvuseni'. - Teater. Muusika. Kino 11, 94-106.

Aumont, Jacques; Bergala, Alain; Marie, Michel; Vernet, Marc 1992. Aesthetics of Film. Trans. Richard Neupert. Austin: University of Texas Press.

Баскаков, Владимир 1964. 'Героическое в кино'. Искусство кино 8, 34-40.

Balázs, Béla 1952. Theory of the Film: Character and Growth of a New Art. London: Dennis Dobson.

Berger, Peter L.; Luckmann, Thomas 1991. The Social Construction of Reality: A Treatise in the Sociology of Knowledge. London: Penguin Books.

Bezzubov, Valeri 1977. Juri Trifonovi proosalooming. Sirp ja Vasar, 23 September.

Дробашенко, Сергей 1962. Экран ижизнь. О

художественном образе в документальном фильме. Москва: Искусство.

Dumanciić, Marko 2010. Rescripting Stalinist Masculinity: Contesting the Male Ideal in Soviet Film and Society, 1953-1968. PhD thesis. University of North Carolina. Chapel Hill. https://cdr.lib.unc.edu/indexablecontent/ uuid:9080556a-0584-4a42-9b6f-a85680bad596 (11 October 2017).

Джулай, Людмила 2005. Документальный иллюзион. Отечественный кинодокументализм - опыты социального творчества. Москва: Материк.

Эйзенштейн, Сергей 1964. Избранные произведени я в шести томах. Том 2. Москва: Искусство.

Ellis, Jack C.; McLane, Betsy A. 2008. A New History of Documentary Film. New York: Continuum.

Эльманович, Татяна 1975. Образ факта. Om

публииистики к фильму на эстонском телевидении.

Москва: Искусство.

Elmanovitš, Tatjana 1976. 'Eesti kinematografistide kongressi eel'. - Sirp ja Vasar, 9 April.

Elmanovitš, Tatjana 1977. 'Dokumentaalfilmidest 1976'

- Sirp ja Vasar, 18 March.

Elme, Toivo 1977. 'Mitte ainult leivast.... - Sirp ja Vasar, 13 May.

Фомин, Валерий (ed.) 2012. История киноотрасли в

России:управление, кинопроизводство, прокат. Москва: НИИК ВГИК

Foucault, Michel 1980. Power/Knowledge: Selected Interviews and Other Writings 1972-1977. Ed. Colin Gordon, trans. Colin Gordon, Leo Marshall, John Mepham, Kate Soper. New York: Pantheon Books. Golovskoy, Val. S; Rimberg, John 1986. Behind the Soviet Screen: The Motion-Picture Industry in the USSR 1972-1982. Michigan: Ardis.

Hall, Stuart 2013. 'The Work of Representation'. - Stuart Hall, Jessica Evans, Sean Nixon (eds.), Representation. 2nd ed. London: Sage, Open University, 1-47.

Hruštšov, Nikita 1963. 'Kõrge ideeline tase ja kunstimeisterlikkus on nõukogude kirjanduse ja kunsti suur jõud. Seltsimees N. S. Hruštšovi kõne partei ja valitsuse juhtide kohtumisel kirjandus- ja kunstitegelastega 8. märtsil 1963'. - Rahva Hääl, 12 March.
Huxtable, Simon 2016. 'The Life and Death of Brezhnev's Thaw: Changing Values in Soviet Journalism after Khrushchev, 1964-1968'. - Dina Fainberg, Artemy M. Kalinovsky (eds.), Reconsidering Stagnation in the Brezhnev Era: Ideology and Exchange. Maryland: Lexington Books, 21-42.

Kanter, Kadri 2014. Eesti NSV kinematograafia ministeerium 1946-1953. Eellugu, tegevuse põhisuunad ja likvideerimine. MA thesis. Tartu Ülikool.

Караганов, Александр 1959. 'Герой наших дней'. Искусство кино 7, 39-47.

Kasik, Reet 2008. 'Meediateksti analüüs: eesmärgid ja metoodika' - Reet Kasik (ed.), Tekstid ja taustad V. Meediatekstide keelekasutus ja selle sotsiokultuurilised taustad. Tartu: Tartu Ülikooli Kirjastus, 10-41. Kosenkranius, Ivar 1974. Film ja aeg. Esseid, etüüde, portreevisandeid. Tallinn: Eesti Raamat. Kreegipuu, Tiiu 2015. 'Ajakirjandus Nõukogude Eestis külma sõja võitlusvahendina'. - Tõnu Tannberg (ed.), Nõukogude Eesti külma sõja ajastul. Tartu: Rahvusarhiiv, 163-199.

Летопись 2010 = Летопись Российского кино, 1946-1965. Москва: Канон+.

Mesila, Tiit 1972. Ringvaade "Nõukogude Eesti". Väljendusvahendid, žanrid ja sisu analüüs. Diploma thesis. Tartu Riiklik Ülikool.

Näripea, Eva 2011. Estonian Cinescapes: Spaces,

Places and Sites in Soviet Estonian Cinema (and Beyond). PhD thesis. Estonian Academy of Arts. Tallinn. http://www.digar.ee/id/nlib-digar:195147 (2 December 2017).

Nichols, Bill 2001. Introduction to Documentary.

Bloomington, Indiana: Indiana University Press.

Oukaderova, Lida 2017. The Cinema of the Soviet Thaw:

Space, Materiality, Movement. Bloomington: Indiana University Press.

Shcherbenok, Andrey 2016. 'Everything Was Over Before It Was No More: Decaying Civilization in Late Stagnation Cinema. - Dina Fainberg, Artemy M. Kalinovsky (eds.), Reconsidering Stagnation in the Brezhnev Era: Ideology and Exchange. Maryland: Lexington Books, 77-84.

Taylor, Richard 1979. The Politics of the Soviet Cinema

1917-1929. Cambridge: Cambridge University Press.

Teinemaa, Sulev 1983. 'Probleemfilmid Valeria

Andersoni moodi'. - Sirp ja Vasar, 16 December.

Vaino, Maarja 2016. Tammsaare irratsionaalne poeetika.

Tallinn: Eesti Keele Sihtasutus.

Västrik, Riho 2015. 'Constructing National Identity

in Soviet Estonian Documentary Cinema: A Case Study

of the Documentary Ruhnu (1965) by Andres Sööt.' -

Baltic Screen Media Review 3, 4-29.

Vellerand, Lilian 1976. 'Töö ja tööline eesti dramaturgias'. - Sirp ja Vasar, 20 February.

Вертов, Дзига 1966. Статьи, дневники, замыслы. Москва: Искусство.

Veskimägi, Kalju-Olev 1996. Nõukogude unelaadne elu. Tsensuur Eesti NSV-s ja tema peremehed. Tallinn: K.-O. Veskimägi.

Власов, Марат 1974. 'Герой, которого требует время'. Искусство кино 9, 1-14.

Woll, Josephine 1993. Invented Truth: Soviet Reality and the Literary Imaginations of Iurii Trifonov. Durham, London: Duke University Press.

Woll, Josephine 2000. Real Images: Soviet Cinema and the Thaw. London, New York: I.B. Tauris. 